College might pay the price of forming the casts, and the public bodies purchase the models, but I think you will agree with me, that if this can be avoided, it will be better. With respect to great head of the Rodent, I certainly feel inclined to run the risk of taking a cast, because the models will be more generally useful, even in case the head itself should be injured or destroyed. But I am sure after the kind and effectual manner with which you have entered on this affair I cannot do better than follow your advice. I, at one time, began to think that the fossil bones would be as troublesome to $m e$ and as of little service as some other branches of my collection are likely to be. But now I look back to the trouble I took in procuring them with great satisfaction. I do assure you I feel very grateful to you for having given me such good assistance. I have scarcely begun to unpack my cases; in the course of a week I shall have every thing open, and I already know of one very large bone (of a Mastodon ??) which I will forward to the College. When separating the animals in spirits, I will put by any that I think will interest you. And it will be a great pleasure to me if I chance to possess anything which will be of use to you in your numberless investigations.

Believe me, my dear Sir, Your very truly obliged Chas. DaRWIN.

Christ Coll :

Cambridge.

To Richard Owen, Esq ${ }^{\mathrm{r}}$

Royal College of Surgeons, Lincoln's Inn Fields.

\section{Biochemical Studies of Spike Disease of Sandal.}

$\mathrm{M}^{\mathrm{r}}$

R. M. SREENIVASAYA and Mr. B. N. Sastri have continued their very detailed investigations into the spike disease of sandal (Santalum album L), and their latest results are to be found in the Journal of the Indian Institute of Science, vol. 12A, Part 17, pp. 233 to 252 (1929). Leaf-juice from a sandal tree infected with the spike disease hydrolyses more soluble starch than does the corresponding healthy juice. This is due to a higher concentration of the enzyme and to the presence of activators such as phosphates and amino acids. The $p \mathrm{H}$ of spiked leaves is lower than that of healthy leaves, and approaches the optimum for diastatic activity. More potato starch is, however, liquefied by the healthy leaf extract than by the diseased extract for equal weights of sugar produced, thus suggesting a qualitative difference between the two diastase extracts. It should be remembered that Dr. I. C. Coleman found that there was lower diastatic activity in spiked leaves than in healthy leaves, and therefore the results here reported might be interpreted as showing that the diastase content of diseased tissue fluctuates within the same limits as does that of healthy tissue.

The chemical composition of leaf and stem tissue fluids has also been investigated. The spike-diseased leaf contains more nitrogen, maltose, and reducing sugars and less ash (particularly calcium) than the healthy leaf. The stem fluids of spike-diseased trees are richer in nitrogen, phosphorus, and calcium than those of healthy plants, and there is a steep gradient of calcium concentration between the stem and leaves.

The seasonal variations in composition of healthy and partially spiked leaves of the sandal tree have been studied by Mr. A. V. Varadaraja Iyengar (Jour. Ind. Inst. Sci., vol. 12A, Part 20, pp. 295-305). Season was found to affect the chemical composition of the leaves of both healthy and spiked plants in the same manner. The following relative differences were observable in all seasons-the diseased sap had less dissolved matter, less osmotic pressure, a greater electrical conductivity, more moisture, ash, and nitrogen contents, less calcium, and was more acid than healthy sap.

These detailed studies on sandal spike from the Indian Institute of Science have considerable significance, for it has recently been shown by Mr. M. J. Narasimhan (Phytopathology, 18, pp. 815-817; 1928) that inclusion bodies similar to those which characterise certain virus diseases are present in leaf tissues of spiked plants. This, along with the work of Dr. L. C. Coleman on transmission, suggests that the malady is caused by a virus. We have thus a mine of detailed information on the chemistry of a diseased host which we can use in the elucidation of the problem of the nature of a plant virus.

\section{University and Educational Intelligence.}

Aberystrwyth.-Dr. C. D. Forde, formerly of the Department of Geography, University College, London, has been appointed to succeed Prof. H. J. Fleure in the chair of geography and anthropology at the University College of Wales, Aberystwyth. Dr. Forde has just returned from the University of California, where he held a fellowship from the Commonwealth Fund, and received the degree of doctor of philosophy for his researches among the Hopi Pueblo Indians of North Arizona.

CAMBRIDGe.-The following have been appointed members of the Committee for the Natural Sciences Tripos for the year 1930-31 : Prof. A. Hutchinson (chairman), Prof. T. M. Lowry, Mr. H. Thirkill, Dr. W. H. Mills, Mr. A. Wood, Mr. E. Cunningham, Mr F. T. Brooks, Mr. T. C. Nicholas, Mr. J. T. Saunders, Dr. Dean, Sir Frederick Gowland Hopkins, Prof. J. Barcroft.

The General Board recommends that a University demonstratorship in pharmacology be established in the Faculty of Medicine.

Mr. Stanley Baldwin was installed as Chancellor of the University on June 5 and in the course of his address announced that the gift from the Rockefeller Foundation had been made available through the completion of the collection of a sum which was made a condition of the grant. The total sum required for the University Library and for research work was $£ 1,179,000$. The Rockefeller Foundation had promised $£ 700,000$ conditional on the balance being raised by the end of 1931. This balance has now been raised.

Honorary degrees were conferred by Mr. Baldwin after his installation on the following, among others : Prof. A. Einstein, of Berlin; Prof. Max Planck, of Berlin; Sir John Rose Bradford, president of the Royal College of Physicians; and Sir James Colquhoun Irvine, principal and vice-chancellor of the University of St. Andrews.

LIVERPOoL.-Among the honorary degrees conferred on June 5 were the following: Doctor of Laws, Mr. R. L. Mond, honorary secretary to the DavyFaraday Research Laboratory of the Royal Institution; Doctor of Science, Prof. G. Barger, professor of chemistry in relation to medicine in the University of Edinburgh.

LONDON.-Applications are invited for the Graham Scholarship in Pathology, value $\mathfrak{£ 3 0 0}$ per annum, in the first instance for two years, founded under the

No. 3163, Vor. 125.] 
will of the late Dr. Charles Graham to enable " a young man to continue his pathological researches and at the same time to secure his services to the School of Advanced Medical Studies connected with University College Hospital as a Teacher under the direction of the Professor of Pathology".

The latest date for the receipt of applications is June 17. They should be sent to the Principal, University of London, South Kensington, S.W.7.

OXFORD.- The question of the destiny of the Rarlcliffe Observatory site and buildings has now come officially before the University in the form of a decree in Congregation. By this it is proposed to accept the offer of Sir William Morris, the purchaser of the site from the Radcliffe Trustees, to vest the whole of the property in the hands of a body of trustees, in order that it may be used for the benefit of the Radcliffe Infirmary and the Medical School of the University. The terms of the trust provide that the old observatory building shall be used for the purpose of medical teaching and research, and that the observer's house and garden shall be used as a residence for the director of the institute of research to be constituted in accordance with these terms.

The report issued by the Curators of the Botanic Garden includes a list of noteworthy plants lately received, and mentions improvements in the labelling of trees, shrubs, and plants.

The Herbert Spencer Lecture, delivered by Sir Peter Chalmers Mitchell, was a vigorous defence of materialistic monism, which, he said, so far from being discredited as a theory by recent advances in physical science, stands now in an even stronger position than in Spencer's day. Not one of the forms of what is called vitalism can, in his opinion, stand the test of critical examination. Progress in science must be achieved, as of old, by the way of experiment and observation.

In a lecture recently delivered in Oxford, Miss Caton-Thompson gave an interesting account of her exploration of the Great Zimbabwe and of other ruins in Rhodesia. She dwelt upon the fact that no evidence of any kind exists to suggest that these remains are of other than Bantu origin, or that they owe anything to outside influence. The stratigraphical evidence which is now available from many sites in Rhodesia all points in the direction of Bantu as against Arab, Phonician, or any other kind of foreign activity.

The New York correspondent of the Times states that Mr. Louis Bamberger, the retired head of Bamberger and Co., Newark, New Jersey, and his sister, Mrs. Felix Fuld, have given $£ 1,000,000$ for the establishment in Newark or the vicinity of an institute for advanced study, exclusively for post-graduate work and scientific research.

Ат a meeting at the Mansion House, London, on June 2, the Lord Mayor presiding, it was announced that a contract had been signed for the purchase of a freehold site in Bloomsbury for 'London House', the proposed hall of residence in London for British male students of European origin from the Dominions and Colonies and from Great Britain. The object of the meeting was to launch an appeal for a fund of $£ 250,000$ to be administered by the Dominion Students' Hall Trust, for which an influential council of governors has been appointed, with Mr. F. C. Goodenough, of Barclay's Bank, as chairman. Towards this fund $£ 130,000$ has already boen contributed. The appeal was supported from the platform by Mr. L. S. Amery,
Mr. H. A. L. Fisher, Mr. Stanley Bruce, Sir James Parr, Sir William Clark, Sir Drummond Chaplin, Lord Moynihan, and Mr. F. C. Goodenough. Special reference was made to the post-graduate medical school to be established at Hammersmith. "London House', while closely associated with the University of London, will be an independent institution and the governing body includes representatives of the University, the Royal Colleges of Surgeons and Physicians, and other professional institutions. The Corporation of the City of London and the Rhodes Trustees have each made a donation of $£ 5000$ to the fund. The Lord Mayor read a letter from the Prime Minister strongly supporting the appeal. "London House", he said, "appeals to common sense, to the spirit of hospitality, to the imagination. Let us look ahead and see the young men of our race coming to London with their vigour and freshness of outlook, intermingling with us and each other, sharing in our heritage of learning and experience and tradition, and returning so equipped to wherever British energy and enterprise have set their homes."

THE Committee of Award for the Commonwealth Fund Fellowships has made appointments to 26 fellowships tenable by British graduates in American universities for the two years beginning September next, including the following: Mr. R. W. Adams (Jelfast) to Massachusetts Institute of Technology, in electrical engineering; Mr. J. T. Calvert (Oxford) to the Massachusetts Institute of Technology, in sanitary engineering; Miss I. G. M. Campbell (St. Andrews) to Cornell University, in organic chemistry; Miss R. L. Cohen (Cambridge) to Stanford University, in agricultural economics; Mr. A. G. Emslie (Aberdeen) to Cornell University, in physics; Mr. H. Fisher (London) to the Massachusetts Institute of Technology, in civil engineering; Mr. G. V. B. Herford (Oxford and London) to the University of Minnesota, in zoologv; Dr. D. W. Hill (Bristol and Liverpool) to the University of Illinois, in biochemistry; Mr. F. L. Hudson (Manchester) to the University of California, in physical chemistry ; Dr. J. Irving (St. Andrews and Cambridge) to Harvard University, in geology ; Mr. T. H. Kelly (Birmingham) to Columbia University, in economics; Mr. J. E. MacColl (Oxford) to the University of Chicago, in economies; Mr. J. E. Meade (Oxford) to Stanford University, in economies ; Mr. A. K. Nuttall (Cambridge) to Stanford University, in electrical engineering; Dr. R. W. B. Pearse (London) to the California Institute of Technology, in physies; $\mathrm{Mr}$. R. W. Revans (London and Cambridge) to the University of Michigan, in physics; Mr. W. J. Sartain (Cambridge) to Yale University, in economics; Mr. W. A. Sinclair (Edinburgh and Oxford) to Harvard University, in philosophy; Mr. S. Steele (Cambridge) to Johns Hopkins University, in aero engineering ; Mr. William Wild (Leeds) to the University of California, in physical chemistry. The following have been appointed to fellowships tenable by candidates from the British Dominions : Mr. N. S. Bayliss (Melbourne and Oxford) to the University of California, in chemistry; Mr. W. G. K. Duncan (Sydney and London) to the University of Chicago, in sociology ; Mr. P. J. Hogan (Dublin and London) to Iowa State University, in civil engineering; Mr. S. J. Pretorius (Stellenbosch and London) to Cornell University, in economic statistics. The following have been appointed to fellowships tenable by candidates holding appointments in Government service overseas: Dr. C. M. Tattam, of the Geological Survey of Nigeria; Mr. C. Vigne, of the Forestry Department, Gold Coast Colony; Capt. R. D. Waghorn, of the Indian State Railways.

No. 3163, VoL. 125] 